Print ISSN: 2233-4165 / Online ISSN 2233-5382

doi:http://dx.doi.org/10.13106/jidb.2020.vol11.no4.47

\title{
The Influence of CEO's Scandal on Consumers' Product Purchase
}

\author{
Ji-Eun CHOI*
}

Received: March 03, 2020 Revised: March 252020 Accepted: April 05, 2020.

\begin{abstract}
Purpose: This study aims to explore how consumers respond to the immoral actions of a CEO. More specifically, this research focuses on the moral reasoning processes used by consumers in order to maintain support for the CEO despite the immoral action. In addition, this research suggests that support for the CEO would improve product purchase intention. Research design, data, and methodology: To test the hypotheses presented, an online research company was hired and online survey was conducted with adult participants. Online research company sent an email to the potential subjects asking their participation in an online survey. Subjects were able to participate in the online survey by clicking a link to the survey. When the participants clicked the link, they were instructed to read a fictitious newspaper article on a CEO's immoral action. And then, they were asked to answer several questions online. Responses were obtained from 336 adults participants and data were analyzed using SPSS Hayes Macro for a moderation effect and AMOS for a structural equation model. Result: Moral reasoning processes were divided into moral decoupling and moral rationalization and analyzed to determine their influence on product purchase. Also in this study, we suggest the public self-consciousness of consumers as an antecedent of moral reasoning processes, and argue that consumers with high public selfconsciousness are more likely to engage in moral decoupling than moral rationalization. Conclusions: Our results showed that moral decoupling and moral rationalization improved the consumer's perception of corporate ethicality, which increased product purchase intention. In addition, consumers with high public self-consciousness were more likely to engage in moral decoupling than in moral rationalization. In addition, this research suggested that severity of the scandal would moderate the impact of public self-consciousness on moral decoupling. However, this hypothesis was not supported statistically since most participants perceived the scandal to be a highly severe incident, that may lead to an insignificant interaction effect between severity of the scandal and public self-consciousness. This research expands the scope of available research on corporate ethics and consumer responses to negative information involving celebrities and provides practical implications for corporate crisis management.
\end{abstract}

Keywords: Moral Decoupling, Moral Rationalization, Perception of Corporate Ethicality, Public Self-Consciousness, Perceived Severity of Incident

JEL Classification Code: M10, M13, M30, M31

\section{1. 서론}

최근 몇몇 기업의 총수 혹은 그 일가의 갑질에 대한 뉴스가 연이어 보도되면서 기업이나 경영인의 윤리란 무엇인가에 대한 소비자들의 논의가 재 점화되었다. 한 향토기업으로 알려진 A 식품회사의 회장은 자신의 운전기사에게 상습적으로 폭언과 폭행을 일삼았다는 이유로 여론의 뭇매를 맞았으며, 이 사건이 해당 기업 제품에 대한 소비자들의 불매운동을 촉발하였다. 기업경영인 혹은 재벌총수들의 비윤리적 행동과 관련된 사건들은 매우 빈번하게 일어나서 언론에서는 이러한

*First Author's Affiliation: Associate Professor, Department of Business Administration, Kangwon National University, Korea, Email: jieun@kangwon.ac.kr

๑) Copyright: Korean Distribution Science Association (KODISA)

This is an Open Access article distributed under the terms of the Creative Commons Attribution NonCommercial License (https://creativecommons.org/licenses/by-nc/4.0/) which permits unrestricted non-
비윤리적 행동들의 행태를 신랄하게 비판하기도 하였다. 이렇게 기업경영인이 부정적 행동을 저질렀을 때 소비자들은 해당 경영인에 대해 부정적으로 반응하기 쉽고, 이러한 부정적 반응은 기업의 매출 감소의 주요한 동인으로 작용할 수 있다. 실제로, 앞서 언급한 기업에 대한 소비자의 반기업 정서와 불매운동은 운전기사 폭행 사건 논란 이후 매출 감소로 이어진 바 있다. 직관적으로도 최고경영자의 부정적 행동은 기업의 성과에 부정적 영향을 미칠 것이라는 예측이 가능하다.

그런데, 최고경영자가 부정적 행동을 저질렀을 때 모든 소비자들이 이에 대해 부정적으로 반응할 것인가에 대해 이론적으로 고찰해볼 필요가 있다. 일반적으로 소비자들은 최고경영자의 이미지와 기업의 이미지를 동일시하는 경우가 많기 때문에, 최고경영자가 부정적 행동을 저지를 경우 이에 대해 부정적으로 반응하기 쉽다. 그리고 이러한 부정적 반응은 기업에 대한 평가에 직접적으로 부정적 영향을 미치기 쉽다. 그러나 특정한 상황에서 소비자들은 최고경영자에 대한 지지를 
유지하기 위하여 그의 도덕성에 관해 우호적인 방향으로 추론할 수도 있을 것이다. 예를 들면, 최고경영자가 사생활에서는 운전기사에게 폭행을 가하는 등의 폭력성을 보이지만 기업 경영에 관한 한 탁월한 성과를 보이는 경우를 생각해볼 수 있을 것이다. 이렇게 최고경영자에 대한 긍정적 정보와 부정적 정보를 소비자가 동시에 접하게 되었을 때 최고경영자를 비난하고 이러한 경영인이 속해있는 기업과의 관계를 종결시키는 소비자들도 있을 수 있다. 그러나 한편으로 이러한 최고경영자의 경영능력을 높게 평가하고 이에 따라 최고경영자의 부정적 행동을 우호적인 방향으로 추론 혹은 재해석함으로써 해당 기업과의 관계를 유지하려는 소비자 또한 존재할 수 있다. 실제로 미국의 전직 대통령인 클린턴은 불륜 사건이 회자된 이후에 대통령으로 당선되었으며, 영화감독으로 상당한 업적을 남긴 로만 폴란스키 감독은 비윤리적인 행동을 저지른 범죄자임에도 영화계의 호평을 받아 아카데미상을 수상한 바 있다(Bhattachajee, Beman, \& Reed, 2013). 이러한 사례는 최고경영자를 포함한 유명인들이 부정적 행동을 저질렀다고 하더라도 모든 소비자들이 이들에 대해 부정적으로 반응하지는 않을 수 있다는 것을 시사한다. 물론 주지해야 할 것은 부정적인 행동을 저지른 인물들이 자신의 본업에서 매우 뛰어난 능력을 보였다는 것이다.

이에, 본 연구에서는 최고경영자가 경영성과는 매우 탁월하지만, 개인적인 영역에서 부정적 행동을 저질렀을 때 이러한 최고경영자를 옹호하기 위한 소비자들이 있을 수 있음에 주목하였다. 그리고 선행연구에 의거하여 최고경영자를 옹호하기 위한 소비자들의 정당화 기제를 크게 도덕적 합리화와 도덕적 분리로 분리한 후, 이러한 정당화 기제가 기업의 윤리성 지각과 제품의 구매의도에 미치는 영향을 규명하고자 한다. 또한 정당화 기제에 영향을 미치는 선행요인은 다양할 수 있는데, 본 연구에서는 소비자의 개인적 특성에 따라 이러한 정당화 기제가 다를 수 있음에 주목하였다. 구체적으로, 사회적인 객체로서의 자아에 습관적으로 주의를 기울이는 개인의 심리적 경향성인 공적자기의식에 따라 정당화 기제가 달라질 수 있음을 제안하고자 한다. 이러한 연구는 기업이나 경영인의 윤리와 관련된 연구, 그리고 유명인의 부정적 행동에 대한 소비자의 정당화 기제와 관련된 연구의 영역을 확장하는데 기여할 것으로 판단된다.

\section{2. 이론적 배경}

\section{1. 유명인의 부정적 행동에 대한 소비자의 정당화 기제}

사람들은 유명인이 부정적인 행동을 저질렀을 때 자신의 도덕적 신념 등을 기준으로 유명인이 도덕적인지 혹은 그렇지 않는지에 대한 결론을
내리는 경향이 있다(Kunda, 1990). 사람들은 유명인이 비도덕적인 행동을 저질렀을 때 유명인에 대해 부정적인 평가를 내리면서 유명인에 대한 지지를 철회할 수도 있지만, 유명인에 대한 지지를 유지하기 위하여 유명인을 정당화하려는 경향을 보이기도 한다(Haidt, 2001). 즉, 사람들은 때로 유명인에 대한 긍정적인 태도를 유지하기 위하여 긍정적인 태도와 불일치하는 부정적인 정보를 정당화함으로써 인지적인 불편함 혹은 부조화를 해소하려 할 수 있다는 것이다.

유명인에 대한 지지를 철회하지 않기 위해 소비자들이 행할 수 있는 정당화 기제에는 크게 두 가지가 있는데, 이러한 정당화 기제를 Bhattachaijee et al.(2013)은 도덕적 분리(moral decoupling)와 도덕적 합리화(moral rationalization)로 개념화하였다. 이 두 가지 정당화 기제 중 도덕적 분리를 살펴보면, 도덕적 분리란 유명인의 부정적 행동을 이들의 탁월한 성과와 분리하는 정보처리방식을 의미한다Bhattachajee et al, 2013). 도덕적 분리는 부정적 행동에 대해 통렬하게 비판하면서도 탁월한 성과를 칭찬하는 방식으로 유명인의 긍정적 측면과 부정적 측면을 분리하는 형태의 정보처리방식인데, 이러한 과정을 통해 소비자는 유명인에 대한 지지를 유지하게 된다. 즉, 소비자가 유명인의 부정적 행동은 비판받아 마땅하지만, 유명인의 성과는 훌륭하기 때문에 유명인을 지지할 수밖에 없다고 말한다면 이러한 정보처리방식은 도덕적 분리에 해당된다.

두 번째 정당화 기제인 도덕적 합리화는 유명인에 대한 지지를 철회하지 않고 유지하기 위하여 유명인의 부정적 행동이 그다지 비도덕적인 것은 아니라고 재해석하는 형태의 정보처리방식을 의미한다(Bhattachajee et al, 2013). 즉, 유명인의 부정적 행동이 다른 유명인들의 더 심각하게 부정적인 행동에 비하여 그렇게 나쁜 것은 아니라거나, 혹은 이들의 부정적 행동에는 다른 이유가 있지 않겠나는 식으로 재해석함으로써 유명인에 대한 지지를 철회하지 않는 것을 의미한다. 유명인의 비도덕성의 정도를 축소하고 이에 대해 변명 혹은 합리화함으로써 소비자는 자신의 도덕적 기준과 유명인에게 기대하는 바람직한 결과 사이에서 야기되는 긴장감을 완화할 수 있다(Bhattachajee et al, 2013).

이 두 가지 정당화 기제를 다룬 연구들은 아직까지 충분히 이루어지지는 않았으나, 몇몇 선행연구들이 도덕적 분리와 도덕적 합리화라는 정당화 기제의 결과요인을 규명하는데 초점을 맞추었다. 이 정당화 기제를 개념화한 연구로 우선 Bhattachajee et al.(2013)의 연구를 들 수 있다. 이들은 정당화 기제를 도덕적 분리와 도덕적 합리화로 분류하면서 이 두 기제가 각기 다른 심리적 반응을 야기함을 규명하였다. 또한 이들은 이 두 가지 정당화 기제를 개념화하면서 도덕적 합리화보다는 도덕적 분리가 더 손쉬운 정당화 기제임을 지적하였다. 이들 연구에 의하면, 도덕적 합리화는 유명인의 부정적 행동이 그렇게 부정적인 것은 아닐 수 있다는 재해석을 의미하는데 이러한 재해석을 위해서는 자신의 도덕적 잣대를 낮추는 과정을 필요로 
한다. 그런데 이러한 도덕적 잣대를 하향 조정하는 것은 자신이 그다지 도덕적인 사람이 아닐 수 있다는 신호로 타인에게 작동할 수 있고, 결과적으로 자아이미지의 손상으로 이어질 가능성이 농후하다. 사람들은 긍정적인 자아이미지를 확립하고 유지하고자 하는데, 도덕적 잣대를 하향조정하는 것은 타인의 비난이나 거부와 같은 사회적 위험을 야기할 수 있다. 또한 자아이미지의 손상은 한 개인의 자존감에도 영향을 미칠 수 있다는 점에서 자기합리화는 사회적 위험 및 개인적 위험을 수반하는 정당화 기제로 볼 수 있을 것이다.

반면에, 도덕적 분리는 유명인의 성과와 이들의 부정적인 행동을 분리해서 정보처리하는 것이기 때문에 도덕적 잣대를 하향 조정할 필요가 없다. 즉, 유명인의 부정적 행동을 마음껏 비난하면서도 이들의 훌륭한 성과는 인정해야 한다는 식의 도덕적 분리는 상대적으로 도덕적 합리화에 비해 손쉬운 정당화 기제에 해당된다(Bhattachajjee et al, 2013).

Bhattachajee et al.(2013)은 기업인의 부정적 행동을 중점적으로 다룬 연구는 아니지만, 정치인이나 운동선수 등 유명인이라 간주되는 사람들이 부정적 행동을 저질렀을 때 이들의 행동을 정당화하는 소비자들이 있을 수 있음을 규명했다는 점에서 본 연구의 근간을 이룬다. Bhattachajjee et al.(2013)의 연구를 좀 더 구체화된 마케팅 맥락에서 재확인한 연구도 있다(Lee, Kwak, \& Moore, 2015). 이들 연구는 스포츠스타의 부정적 행동에 대한 정당화 기제인 도덕적 분리와 도덕적 합리화가 스포츠스타가 광고하는 브랜드에 대한 태도와 구매의도에 긍정적 영향을 미침을 규명하였다. 기업 맥락에서 소비자들의 정당화 기제를 다룬 연구도 이루어졌다(Haberstroh, Orth, Hoffmann, \& Brunk, 2017). 이들 연구에서는 비윤리적 기업에 대한 소비자의 정당화 기제로 특히 도덕적 분리에 초점을 맞추었으며, 제품에 대한 관여도가 높으면 도덕적 분리가 제품의 구매의도에 더 많은 영향을 미침을 규명하였다. 그러나 아직까지 소비자의 정당화 기제에 영향을 미치는 영향요인이나 결과요인을 다룬 연구들은 충분하지 않다. 따라서 다양한 맥락에서 선행연구를 재검증하고 확장함으로써 소비자의 정당화 기제에 대한 심도 있는 논의가 필요한 시점이다.

\section{2. 정당화 기제의 결과요인: 최고경영자의 부정적 행동에 대한 소비자의 정당화 기제가 기업 성과에 미치는 영향}

앞에서는 유명인, 스포츠스타, 혹은 기업이 부정적 행동을 저질렀다고 하더라도 이들에 대한 지지를 철회하지 않고 유지하려는 소비자가 있을 수 있음을 지적하였다. 그리고 소비자가 이들에 대한 부정적 정보를 정당화하는 식의 정보처리를 통해 부정적 정보가 야기하는 심리적 불편감 혹은 인지부조화를 해소할 수 있음을 지적하였다. 물론, 이러한 정당화 기제가 일어날 수 있는 가장 기본적인 조건 중에 하나는 이러한
유명인이나 스포츠스타가 나름의 훌륭한 성과를 내고 있다는 것이다(Bhattacharjee et al, 2013; Haberstroh et al, 2017; Lee et al, 2015). 즉, 훌륭한 성과를 내고 있지 않은 정치인 혹은 스포츠스타가 부정적 행동을 저질렀을 경우 소비자는 정당화의 필요성을 느끼지 못하고 이들에 대한 지지를 손쉽게 철회할 것이다. 따라서 정당화 기제는 유명인이 훌륭한 성과를 내고 있는 상황에 한정하여 나타날 수 있는 정보처리방식이라고 할 수 있다.

그렇다면, 본 연구의 맥락으로 돌아와서 기업의 최고경영자가 기업인으로서 훌륭한 성과를 내고 있지만, 기업 경영과는 무관한 부정적 행동을 저질렀을 때 소비자들이 어떠한 반응을 보일 것인가에 대해 고찰할 필요가 있다. 소비자의 정당화 기제와 관련된 선행연구에서는 부정적 행동에 대한 정당화 기제가 소비자의 긍정적 반응에 영향을 미칠 수 있음을 규명하였다. 예를 들면, Bhattachajjee et al.(2013)은 도덕적 분리와 도덕적 합리화가 모두 유명인에 대한 지지에 긍정적 영향을 미침을 규명하였으며, Lee et al.(2015)은 스포츠스타에 대한 도덕적 분리와 도덕적 합리화가 스포츠스타가 광고하는 브랜드의 태도와 구매의도에 긍정적 영향을 미침을 규명하였다. 따라서 최고경영자의 부정적 행동에 대한 정당화 기제로서의 도덕적 분리와 도덕적 합리화가 소비자의 긍정적 반응을 야기할 것이라는 추론이 가능하다. 본 연구에서는 소비자의 반응으로 소비자가 지각한 기업윤리와 제품의 구매의도에 초점을 맞추었다. 그리고 최고경영자의 부정적 행동에 대한 정당화 기제가 기업윤리에 대한 소비자 지각과 제품의 구매의도에 연이어 영향을 미칠 것임을 제안하고자 한다.

기업윤리를 다룬 많은 연구들은 기업의 사회적 책임(이하 CSR, Corporate Social Responsibility)에 주로 초점을 맞추어왔다. 그리고 이들 연구들은 기업의 사회적 책임활동이 기업의 긍정적 성과로 이어질 수 있음을 규명하여 왔다. 즉, $\mathrm{CSR}$ 활동은 기업에 대한 긍정적 감정을 유발하고, 기업에 대한 신뢰, 기업에 대한 평판, 기업의 충성도를 향상시키는데 기여한다. 또한 CSR 활동은 산업별로 다를 수 있지만, 전반적으로 기업의 재무적 성과에도 상당한 영향을 미친다. 이렇듯 $\mathrm{CSR}$ 활동과 같은 기업의 윤리적 활동은 기업에 대한 소비자 반응에 긍정적 영향을 미치는 것으로 알려져 있다. 기업의 윤리성과 관련하여 기업의 자선(이하 CP: Corporate Philanthropy)을 중점적으로 다룬 연구들도 있다. 이들 연구에서는 기부와 같은 $\mathrm{CP}$ 활동이 기업의 명성에 긍정적 영향을 미침을 규명하였으며(Brammer \& Millington, 2005; Williams \& Barrett, 2000), 한 이론 연구에서는 CP 활동이 결국 기업의 재무성과에 긍정적 영향을 미칠 것이라고 주장하였다(Godfrey, 2005). 이렇듯, 기업의 윤리성과 밀접하게 연관된 $\mathrm{CSR}$ 활동이나 $\mathrm{CP}$ 활동들은 소비자의 긍정적 반응을 야기함을 알 수 있다. 주목할 점은 이들 연구들의 상당수는 기업이 실제로 윤리적 활동을 얼마나 많이 했는가가 아니라 기업의 윤리적 활동에 대해 소비자가 어떻게 지각하는가에 초점을 맞추었다는 점이다예. Park, Choi, \& Yeu, 2016; Vlachos, Tsamakos, Vrechopoulos, \& 
Avramidis, 2009 등). 즉, 기업의 윤리성과 관련된 활동도 중요하지만, 기업의 윤리성에 대한 소비자의 지각 또한 중요할 수 있다. 그리고 소비자의 기업 윤리성 지각은 기업에서 판매하는 제품의 구매와 같은 기업 성과에 긍정적 영향을 미칠 가능성이 높다(Cho \& Ju, 2015; Hahn, 2015).

이렇듯, 기업의 윤리적 활동이나 기업에 대한 소비자의 윤리성 지각은 기업의 성과에 긍정적 영향을 미칠 수 있는데, 이러한 기업의 사회적, 윤리적 활동을 이끄는 핵심 역할을 하는 것은 기업의 리더인 최고경영자이다. 최고경영자는 기업의 청사진을 제안할 뿐만 아니라 기업의 브랜드 인지도를 높이는데 중요한 역할을 하는 경우가 많다. 이에 소비자들은 최고경영자와 기업을 동일한 것으로 받아들이기도 하며, 최고경영자의 평판이 기업의 평판을 넘어서는 경우도 존재한다. 일례로, 고인이 된 스티브잡스는 애플의 명성을 만든 장본인이며, 애플의 명성을 뛰어넘었다고 해도 과언이 아닐 것이다. 이렇게 기업의 최고경영자와 기업은 불가분의 관계이며, 최고경영자에 대한 소비자의 인식은 기업에 대한 인식에 상당한 영향을 미친다. 따라서 기업의 최고경영자가 부정적 행동을 저질렀을 때 이러한 행동에 대한 소비자의 정보처리는 기업의 윤리성에 대한 소비자 인식에 영향을 미치게 된다.

본 연구의 맥락인, 업무 성과는 탁월하지만 개인이 사생활 영역에서 부정적 행동을 저지른 최고경영자를 소비자가 접하게 되었을 때 소비자들은 이러한 최고경영자에 대한 지지를 철회할 수도 있지만, 이러한 최고경영자에 대한 지지를 유지하고자 할 수도 있을 것이다. 최고경영자의 부정적 행동에 대한 소비자의 정당화 기제로서의 도덕적 분리와 도덕적 합리화는 최고경영자에 대한 인식에 해당한다. 그런데 선행연구에 근거했을 때 최고경영자는 기업과 불가분의 관계에 있기 때문에 최고경영자에 대한 인식은 결국 기업의 윤리성 지각에 유의한 영향을 미칠 수 있을 것이다. 즉, 최고경영자에 대한 지지를 유지하기 위한 정당화 기제인 도덕적 분리와 도덕적 합리화를 하는 소비자들은 최고경영자가 속한 기업 또한 윤리적이라고 인식할 수 있다는 것이다. 도덕적 분리와 도덕적 합리화는 정보처리방식은 다르지만, 유명인의 지지를 유지하려는 정당화 기제에 해당된다. 따라서 도덕적 분리와 도덕적 합리화 모두가 기업윤리 지각에 긍정적 영향을 미친다는 다음의 가설을 제안하였다.

가설 1: 도덕적 분리를 많이 할수록 기업윤리를 긍정적으로 지각할 것이다.

가설 2: 도덕적 합리화를 많이 할수록 기업윤리를 긍정적으로 지각할 것이다.

다음으로, 기업의 윤리성 지각이 기업의 구매의도에 미치는 영향을 제안하기 위하여 관련 연구들을 살펴보면, 이 둘 간의 긍정적 관련성을 보인 선행연구들이 있다. 우선, 기업의 윤리적 활동을 다룬
선행연구들은 이러한 활동들이 소비자의 긍정적 반응을 야기할 수 있음을 규명하여 왔다. 예를 들면, 소비자들이 CSR 활동을 윤리적이라고 인식할수록 구전의도나 기업에 대한 충성심이 높아진다는 것을 규명한 연구나 기업의 자선적 활동이 기업에 대한 충성심에 긍정적 영향을 미친다는 것을 규명한 연구(예. Park et al, 2016) 등을 들 수 있다. 이러한 연구는 기업의 윤리적 활동이 기업에 대한 인식과 소비자의 행동에 긍정적 영향을 미칠 수 있음을 규명하고 있는데(Lee \& Lee, 2014), 이러한 연구 결과는 기업의 윤리성과 소비자의 반응 간의 연관성을 시사하는 것이다. 이에, 본 연구에서는 선행연구에 기반하여 소비자가 기업윤리를 긍정적으로 지각할수록 제품의 구매의도가 높게 나타날 것이라는 다음과 가설을 제안하였다.

가설 3: 기업윤리를 긍정적으로 지각할수록 제품의 구매의도가 높을 것이다.

\section{3. 정당화 기제의 영향요인: 공적자기의식이 정당화 기제에 미치는 영향}

사람들은 습관적으로 자기 자신에게 주의를 기울이는데, 특히 자신을 사회적 대상으로 간주하면서 습관적으로 자기 자신에게 관심을 기울이는 것을 공적자기의식(public seff-consciousness)이라고 한다Fenigstein, Scheier, \& Buss, 1975). 공적자기의식이 높은 사람들은 자아의 사회적 측면에 습관적으로 관심을 가지며 사회적인 거절에 민감하게 반응한다. 따라서 공적자기의식이 높은 사람들은 동료집단의 거절이나 무시를 경험했을 때 더 많이 기분나빠하며 추후 자신을 거절한 동료집단과의 상호교류를 덜 하려는 경향을 보인다(Tumer, Gilliand, \& Klein, 1981). 또한 공적자기의식이 높은 사람들은 자신의 외모가 타인이 자신을 평가하는 중요한 단서가 된다고 생각하기 때문에 자신이 이상적이라고 생각하는 외모를 추구하며, 자신의 이상적 외모와 실제 모습과의 간극이 발생할 때 이에 대해 더 많이 걱정하는 경향을 보인다(Miller, Davis, \& Rowold, 1982). 공적자기의식이 높은 사람들이 매력적인 외모를 가진 경우가 많다는 연구 결과를 보인 연구도 있다Tumer et al, 1981). 이러한 결과에 대해 연구자들은 공적자기의식이 높은 사람들은 사회적 객체로서의 자아에 주의를 기울이기 때문에 타인에 대한 인상관리의 일환으로 매력적 외모를 가지기 위해 노력했을 가능성이 높고, 또한 매력적인 외모를 가진 사람들이 성장 과정에서 주위의 긍정적인 평가들을 접하면서 사회적 판단에 민감하게 반응하는 공적자기의식이 생겨났을 수도 있다고 지적하였다.

공적자기의식은 사회심리학 분야에서 제안된 개념이기는 하지만, 마케팅 맥락에서도 주요한 변수로 연구되어 왔다. 예를 들면 공적자기의식이 높은 사람들은 인상관리를 중요하게 생각하기 때문에 
자신의 긍정적 이미지를 표현하기 위한 활동들을 많이 하는 것으로 알려져 있다. 예를 들면, SNS 에 자신을 표현하기 위한 사진을 빈번하게 게시하거나(Shim, Lee, \& Park, 2008), 자신의 이미지를 표현해줄 수 있는 브랜드를 구입하는 행동 등은 모두 높은 공적자기의식과 관련된 행동이라고 볼 수 있다. 즉, 공적자기의식이 높은 사람들은 타인의 시선을 의식하며, 외부의 기준에 민감하게 반응하고 이러한 기준에 부합하는 긍정적인 자아이미지를 구축하기 위해 노력한다. 본 연구에서도 공적자기의식이 높은 소비자는 공적자기의식이 낮은 소비자와는 대별되는 정당화 기제를 사용할 수 있음에 주목하고자 한다 전술하였듯이, 도덕적 합리화란 유명인의 부정적인 행동이 다른 유명인들과 비교했을 때 그렇게 나쁜 것은 아니라는 식으로 정당화하는 것을 의미하는 반면에, 도덕적 분리란 유명인의 부정적인 행동은 나쁘지만 유명인의 성과는 훌륭하다는 식으로 정당화하는 것을 의미한다. 즉, 도덕적 합리화는 자신의 도덕적 잣대를 낮춤으로써 유명인의 부정적 행동을 합리화하지만, 도덕적 분리는 유명인의 부정적 행동을 나쁘다고 꾸짖으면서도 그의 성과는 부정적 행동과는 별개라는 식으로 정당화하기 때문에 자신의 도덕적 잣대를 수정할 필요가 없다(Bhattacharjee et al, 2013). 따라서 도덕적 합리화는 자신의 도덕적 잣대를 하향 조정하는 것과 관련된 사회적 위험을 수반한다(Bhattachajee et al, 2013). 즉, 자신이 낮은 도덕적 잣대를 가질 수 있는 사람이라는 것이 타인에게 알려짐으로써 타인의 비난이나 거절 등을 받을 가능성이 존재한다는 점에서 도덕적 합리화는 도덕적 분리 대비 사회적 위험이 높은 정당화 기제에 해당한다고 볼 수 있다. 공적자기의식이 높은 소비자는 타인의 평가에 민감하게 반응하며(Tumer et al, 1981), 자신의 이상적 이미지를 상대에게 표현하기 위해 노력한다. 따라서 최고경영자가 부정적 행동을 저지른 상황에서 공적자기의식이 높은 소비자들은 사회적 위험이 상대적으로 높은 도덕적 합리화보다는 자신의 도덕성과 관련된 긍정적 인상형성이 가능한 도덕적 분리를 자신의 정당화 기제로 선택할 가능성이 높다. 따라서 공적자기의식과 도덕적 합리화와의 관련성보다는 공적자기의식과 도덕적 분리와의 관련성이 더 높게 나타날 것이라는 다음의 가설을 제안하였다.

가설 4: 공적자기의식과 도덕적 합리화와의 관련성보다는 공적자기의식과 도덕적 분리와의 관련성이 더 높게 나타날 것이다.

그런데, 공적자기의식이 높은 소비자가 도덕적 분리라는 정당화 기제를 선택한다고 하여도 이러한 영향은 사건의 심각성에 따라 달리 나타날 수 있을 것이다. 사건의 심각성은 개별적 사건의 종류에 따라서 달라질 수도 있지만, 동일한 사건이라고 하더라도 소비자들이 지각하는 사건의 심각성은 달라질 수 있다. 본 연구에서는 최고경영자의 부정적 행동에 대해 소비자가 지각하는 심각성의 정도에 초점을 맞추었다.
소비자들이 사건의 심각성을 높게 지각할수록 최고경영자에 대한 정당화 기제가 상대적으로 약화되리라는 것은 직관적으로 예측 가능하다. 그런데 공적자기의식과 사건의 심각성 지각 간의 상호작용효과가 정당화 기제에 어떠한 영향을 미칠 것인가에 대한 고찰이 필요할 것이다.

공적자기의식이 높은 소비자들은 사회적으로 바람직한 자신의 모습을 만들어내기 위해 자신의 도덕적 잣대를 하향 조정할 필요가 없는 도덕적 분리를 선택할 것이라고 제안한 바 있다. 그런데 사건의 심각성이 높으면, 사건의 심각성이 낮을 때보다 상대적으로 최고경영자의 부정적 행동을 정당화하려는 소비자의 동인이 약해지기 쉽다. 이와 관련하여 브랜드 위기상황을 다룬 연구들에서는 브랜드 위기와 관련된 상황을 소비자가 심각하게 지각할수록 기업을 더 많이 비난하게 된다고 하였다(Laufer, Gillespie, McBride, \& Gonzalez, 2005). 즉, 특정 제품의 결함 등으로 소비자가 다치는 사고가 발생했을 때 책임 소재가 불분명한 상황이라 할지라도 소비자들이 이 사건을 심각하게 지각하는 경우에는 기업에게 책임을 돌리면서 기업을 비난하는 경향이 높게 나타난다는 것이다(Jun, Ju, \& Jun, 2009).

이들 연구는 브랜드 위기상황을 다루고 있기는 하나 최고경영자의 명성은 기업 브랜드에 막대한 영향을 미치며, 기업 브랜드와 동일시되는 경우도 빈번하다는 점에서, 이들 연구 맥락을 본 연구에 적용해볼 수 있을 것이다. 공적자기의식이 높은 소비자는 사회적 적합성이나 바람직함을 중요하게 고려하기 때문에 도덕적 분리를 주요한 정당한 기제로 선택하려 하지만, 사건의 심각성이 높은 상황에서는 정당화 기제 선택에 대해 심적 부담을 느낄 가능성이 높다. 왜냐하면 공적자기의식이 높은 소비자는 이상적 자아의 모습을 타인에게 전달하고자 하는 경향성이 높게 나타나는데(Miller et al, 1982), 사건의 심각성이 높을수록 최고경영자를 정당화하는 것은 상당한 소비자의 심적 부담을 수반할 수 있기 때문이다. 따라서 본 연구에서는 지각된 사건의 심각성이 높은 경우보다는 낮은 경우에 공적자기의식이 도덕적 분리에 더 많은 영향을 미칠 것이라는 다음의 가설을 제안하였다.

가설 5: 지각된 사건의 심각성이 높은 경우보다는 낮은 경우에 공적자기의식이 도덕적 분리에 더 많은 영향을 미칠 것이다.

\section{3. 연구방법}

\section{1. 연구 설계 및 자료 수집}

가설 검정을 위하여 온라인 조사업체를 통해 온라인 설문을 실시하였다. 온라인 조사업체는 설문을 소개하는 이메일을 패널에게 
발송하였으며, 설문을 원하는 사람들이 URL 을 클릭함으로써 온라인 설문에 참여할 수 있도록 하였다. 사전에 응답자의 직업, 연령, 학력 등에 대한 별도의 제한을 두지 않았기 때문에 각기 다른 직업, 연령, 학력을 지닌 사람들이 응답자로 참여할 수 있었다. 설문은 부정적 행동을 저지른 경영인에 대한 정당화 기제를 측정하기 위한 것이기 때문에 가상의 설문기사를 제시한 후 응답자들이 일련의 측정항목에 응답하도록 구성하였다. 우선, 신문기사는 부정적 행동을 저지른 유명인사의 실제 기사를 참조하여 제작하였다. 신문기사에서는 작년 사상 최대의 실적을 올린 기업의 최고경영자가 운전기사에게 폭언을 하였다는 내용을 주요한 내용으로 담았다. 구체적으로, Bhattachajee et al.(2013)의 연구 방법을 참고하여, 신문기사에는 최고경영자의 능력이 탁월하다는 내용과 함께 최고경영자가 운전기사에게 상습적으로 폭언을 했었다는 운전기사의 인터뷰를 다루었다. 이렇게 최고경영자의 경영능력과 관련된 내용을 사람들에게 제공한 이유는 소비자들이 탁월한 경영능력을 지닌 최고경영자가 부정적 행동을 저질렀을 때 이에 대해 어떻게 반응하는가를 알아보기 위함이다. 본 연구에서는 신문기사의 헤드라인에 최고경영자에 대한 긍정적 정보와 부정적 정보를 동시에 담았다. 또한 신문기사를 최대한 간략하게 작성하여 최고경영자와 관련된 긍정적 정보와 부정적 정보가 최대한 응답자들에게 시간적 순서 없이 동시에 전달될 수 있도록 하였다.

본 연구에서는 최고경영자의 부정적 행동이 기업에서 판매하는 제품의 재구매에 미치는 영향을 알아보기 위하여 실제 기업을 대상으로 신문기사를 제작하였다. 우선, 신문기사를 제시하기에 앞서 설문 앞 단에 응답자가 최근에 구입한 제품이나 서비스가 있다면, 이러한 제품이나 서비스를 판매하는 기업을 기재하도록 하였다. 이후 응답자들에게 신문기사를 제시하였는데, 신문기사에는 응답자들이 기재한 기업의 이름이 신문기사의 헤드라인과 컨텐츠에 자동으로 나타나게 설계되었다. 예를 들면, 설문 앞 단에 $\mathrm{A}$ 기업의 제품을 구입했다고 응답한 사람들에게는 "작년 사상 최대의 실적을 올린 $\mathrm{A}$ 기업의 회장, 운전기사에게 폭언"이라는 헤드라인과 함께 신문기사의 내용이 제시되게 하였다. 응답자들이 신문기사를 면밀하게 검토할 수 있도록 일정 시간이 지나야 다른 페이지로 넘어갈 수 있도록 하였다. 응답자들은 신문기사를 읽은 후 일련의 설문 항목에 응답하도록 하였다. 설문의 마지막에는 인구통계적 변수를 측정한 후 설문을 마무리하였다. 설문에는 총 336 명이 참여하였는데, 응답자의 평균 나이는 35.33 세였으며, 성별은 남성 $49.1 \%$, 여성 $50.9 \%$ 로 균등한 비율을 이루었다.

\section{2. 변수 측정}

본 연구에서 제안한 가설을 검정하기 위하여 사건의 심각성, 공적자기의식, 도덕적 분리, 도덕적 합리화, 기업의 윤리성, 제품의
재구매의도를 측정하였다. 신문기사에서는 응답자가 기재한 기업명이 나타나도록 하였기 때문에 실제 기업에 대해 응답자들이 가지고 있는 인식이 결과에 영향을 미칠 가능성을 배제할 필요가 있다. 이에, 신문기사의 앞 단에 응답자들이 인식하고 있는 기업의 윤리성과 제품의 재구매의도를 측정한 후 신문기사를 제시하였다. 그리고 기업의 윤리성과 제품의 재구매의도를 다시 측정한 후 신문기사의 제시 이후의 응답에서 이전의 응답을 빼는 방법으로 변화량을 계산하여 분석에 활용하였다기업의 윤리성 변화량: 사후 응답-사전 응답, 제품의 재구매의도 변화량: 사후 응답-사전 응답). 따라서 이 변화량 지수가 양의 값을 지니면 해당 기업에 대한 윤리성과 재구매의도가 긍정적인 방향으로 변화했음을 의미한다.

기업의 윤리성은 Kang(2018)의 연구에서 사용된 3 문항으로 측정하였으며, 제품의 재구매의도는 Zhang(1996)의 연구에 근거하여 3 문항으로 측정하였다. 사건의 심각성과 공적자기의식, 그리고 도덕적 분리와 도덕적 합리화는 신문기사 제시 이후에 응답자들이 응답하도록 하였다. 사건의 심각성은 Jun et al.(2009)의 연구에 근거하여 신문기사에 제시된 사건에 대한 소비자 지각을 2 문항으로 측정하였으며, 공적자기의식은 Choi, Lee, \& Jang(2013)에서 사용된 3 문항으로 측정하였다. 본 연구의 주요한 변수인 도덕적 분리와 도덕적 합리화는 Bhattachajee et al.(2013)의 연구에서 사용된 문항을 본 연구에 맞게 수정하여 도덕적 분리는 3 문항으로, 도덕적 합리화는 5 문항으로 측정하였다. 모든 변수들은 7점 척도로 측정하였다.

\section{4. 분석결과}

신뢰도와 상관관계 분석을 위하여 SPSS 를 사용하였으며, AMOS 의 구조방정식모형 분석을 통해 측정모델과 제안모델을 분석하였다. 분석 결과는 다음과 같다.

\section{1. 측정 항목의 타당성과 신뢰성 분석 결과}

측정모델 분석을 통해 측정항목들의 타당성을 알아보았다. 전술하였듯이 기업의 윤리성과 제품의 재구매의도는 신문기사 이후의 응답과 이전의 응답의 차이를 계산한 변화량을 기준으로 분석을 실시하였다. 측정모델의 적합도 개선을 위하여 SMC(Squared Multiple Correlation)가 낮은 문항이 있는가를 점검하였으며, 최종적으로 도덕적 분리를 측정하는 세 문항 중 첫 번째 문항이 제거되었다. 문항 제거 후 측정모델을 분석한 결과, 적합도는 전반적으로 양호한 것으로 나타났다 $\left(x^{2}=196294, \mathrm{df}=120(\mathrm{p}<0.001), \mathrm{GH}=0.940, \mathrm{AGH}=0.915, \mathrm{NH}=0.964\right.$, IF $=0.986, \mathrm{CH}=0.986$, RMSEA $=0.044$ ). 
다음으로 판별타당성(discriminant validity)과 수렴타당성(convergent validity)을 알아보기 위하여 선행연구에서 제안한 방법에 의거하여 구성개념신뢰도(CR: construct reliability)와 평균분산지수(AVE: average variance extracted)를 계산하였다(Raykov, 1997). 분석 결과, 모든 측정항목의 구성개념신뢰도는 기준치인 0.7 을 상회하였으며,
평균분산지수는 0.6 를 상회하는 것으로 나타났다(<표 1> 참조). 또한 평균분산지수의 제곱근은 구성개념간의 상관관계보다 큰 것으로 나타났다<표 2> 참조). 따라서 측정항목들의 타당성이 확보되었다고 판단하였다.

Table 1: Measurement Model

\begin{tabular}{|c|c|c|c|c|c|c|c|c|}
\hline & U.Beta & S.Beta & S.E. & $\mathbf{t}$ & p-value & Cron- $\alpha$ & AVE & CR \\
\hline \multirow{5}{*}{$\begin{array}{c}\text { Public } \\
\text { Self-Consciousness }\end{array}$} & 1.000 & .753 & & & \multirow{3}{*}{$\begin{array}{l}* * * \\
* * *\end{array}$} & \multirow[t]{3}{*}{.867} & \multirow[t]{3}{*}{.690} & \multirow[t]{3}{*}{.869} \\
\hline & 1.165 & .875 & .076 & 15.298 & & & & \\
\hline & 1.121 & .860 & .074 & 15.220 & & & & \\
\hline & 1.000 & .974 & & & \multirow[b]{2}{*}{$* * *$} & \multirow[t]{2}{*}{.943} & \multirow[t]{2}{*}{.895} & \multirow[t]{2}{*}{.944} \\
\hline & 1.005 & .918 & .056 & 17.843 & & & & \\
\hline \multirow{2}{*}{ Moral Decoupling } & .925 & .810 & .054 & 16.982 & $* * *$ & .868 & .778 & .874 \\
\hline & 1.000 & .949 & & & & & & \\
\hline \multirow{5}{*}{ Moral Rationalization } & 1.000 & .778 & & & \multirow{5}{*}{$\begin{array}{l}* * * \\
* * * \\
* * * \\
* * *\end{array}$} & \multirow[t]{5}{*}{.934} & \multirow[t]{5}{*}{.748} & \multirow[t]{5}{*}{.936} \\
\hline & 1.037 & .897 & .055 & 18.732 & & & & \\
\hline & 1.128 & .931 & .057 & 19.680 & & & & \\
\hline & 1.021 & .793 & .064 & 15.956 & & & & \\
\hline & 1.074 & .915 & .056 & 19.240 & & & & \\
\hline \multirow{3}{*}{ Corporate Ethicality } & 1.000 & .864 & & & \multirow{3}{*}{$\begin{array}{l}* * * \\
* * *\end{array}$} & \multirow[t]{3}{*}{.927} & \multirow[t]{3}{*}{.811} & \multirow[t]{3}{*}{.927} \\
\hline & 1.119 & .924 & .047 & 23.567 & & & & \\
\hline & 1.063 & .913 & .046 & 23.143 & & & & \\
\hline \multirow{3}{*}{ Purchase Intention } & 1.000 & .946 & & & \multirow{3}{*}{$\begin{array}{l}* * * \\
* * *\end{array}$} & \multirow[t]{3}{*}{.965} & \multirow[t]{3}{*}{.901} & \multirow[t]{3}{*}{.965} \\
\hline & 1.043 & .964 & .027 & 39.166 & & & & \\
\hline & 1.001 & .939 & .029 & 35.121 & & & & \\
\hline
\end{tabular}

Notes: $* * *$ indicates that the estimated coefficients are statistically significant at $1 \%$ level respectively.

Table 2: Correlation Matrix

\begin{tabular}{|c|c|c|c|c|c|c|}
\hline & 1 & 2 & 3 & 4 & 5 & 6 \\
\hline $\begin{array}{c}\text { Public } \\
\text { Self- } \\
\text { Consciousness } \\
\text { (1) }\end{array}$ & $.831 *$ & & & & & \\
\hline $\begin{array}{l}\text { Severity of } \\
\text { Incident } \\
\text { (2) }\end{array}$ & .222 & $.946^{*}$ & & & & \\
\hline $\begin{array}{c}\text { Moral } \\
\text { Decoupling } \\
\text { (3) }\end{array}$ & .026 & -.399 & $.882 *$ & & & \\
\hline $\begin{array}{c}\text { Moral } \\
\text { Rationalization } \\
\text { (4) }\end{array}$ & -.040 & -.399 & 696 & $.865^{*}$ & & \\
\hline $\begin{array}{c}\text { Corporate } \\
\text { Ethicality (5) }\end{array}$ & -.142 & -.242 & .341 & .301 & $.900 *$ & \\
\hline $\begin{array}{c}\text { Purchase } \\
\text { Intention } \\
\text { (6) }\end{array}$ & -.170 & -.314 & .513 & .428 & .595 & $.949 *$ \\
\hline
\end{tabular}

Notes: * indicates square root of AVE.

\section{2. 가설 검정}

변수이기 때문에 Hayes(2009)의 SPSS Process 를 활용하여 조절효과를 분석하였다(모델 1). Hayes(2009)의 모델 1 은 독립변수, 조절변수, 종속변수 간의 관련성을 분석하는 구조방정식모형의 제안모델을 분석한 결과, 적합도는 수용 가능한 수준이었으며 $\left(x^{2}=404.681\right.$, $\mathrm{df}=127(\mathrm{p}<0.001), \mathrm{GH}=0.889, \mathrm{AGH}=0.850, \mathrm{NH}=0.927, \mathrm{IH}=0.949, \mathrm{CH}=0.948$, $\mathrm{RMSEA}=0.081$ ), 전반적으로 가설이 지지되는 것으로 나타났다. 구체적으로, 가설 1, 2, 3 에서는 최고경영자의 부정적 행동에 대한 정당화 기제인 도덕적 분리와 도덕적 합리화가 기업에 대한 윤리성 지각과 제품의 재구매의도에 긍정적 영향을 미칠 것이라 제안하였다. 분석 결과, 이러한 가설은 지지되는 것으로 나타났다. 다음으로, 가설 4 에서는 정당화 기제의 영향요인으로 공적자기의식을 제안하였다. 분석 결과, 소비자의 공적자기의식은 도덕적 합리화에 영향을 미치지 않은 반면에 도덕적 분리에는 긍정적 영향을 미치는 것으로 나타났다. 
따라서 공적자기의식이 높을수록 도덕적 합리화보다는 도덕적 분리를 더 많이 할 것이라는 가설 4 가 지지되었다<표 3 > 참조).

Table 3: Hypotheses Test

\begin{tabular}{|c|c|c|c|c|}
\hline Path & U.Beta & S.Beta & C.R. & $\begin{array}{c}\text { p- } \\
\text { value }\end{array}$ \\
\hline $\begin{array}{c}\text { Public Self-Consciousness } \\
\text {--> Moral Decoupling }\end{array}$ & .206 & .129 & 2.222 & .026 \\
\hline $\begin{array}{c}\text { Public Self-Consciousness } \\
-->\text { Moral Rationalization }\end{array}$ & .079 & .065 & 1.155 & .248 \\
\hline $\begin{array}{c}\text { Moral Decoupling } \\
\text {--> Corporate Ethicality }\end{array}$ & .218 & .272 & 4.464 & .000 \\
\hline $\begin{array}{c}\text { Moral Rationalization } \\
->\text { Corporate Ethicality }\end{array}$ & .158 & .150 & 2.645 & .008 \\
\hline $\begin{array}{c}\text { Corporate Ethicality } \\
-->\text { Purchase Intention }\end{array}$ & .815 & .598 & 11.483 & .000 \\
\hline
\end{tabular}

마지막으로, 가설 5 에서는 사건의 심각성이 낮은 상황에서 공적자기의식이 도덕적 분리에 더 많은 영향을 미칠 것이라고 제안하였다. 사건의 심각성과 공적자기의식은 연속형 모델로, 독립변수나 조절변수에 연속형 변수가 포함되어 있을 때 연속형 변수의 특정한 구간에 따른 종속변수의 변화를 보다 면밀하게 살펴볼 수 있기 때문에 이 분석법을 활용하였다. 모든 변수는 평균중심화(meancentering)한 후 분석에 활용하였다. 분석 결과, 두 변수간의 조절효과는 유의하지 않은 것으로 나타나 가설 5 가 기각되었다 $(\mathrm{p}>0.05$, <표 4> 참조).

Table 4: Moderating effect of Incident's Severity

\begin{tabular}{|c|c|c|c|c|c|c|}
\hline & Beta & S.E. & t-value & $\begin{array}{c}\text { p- } \\
\text { value }\end{array}$ & LLCI & ULCI \\
\hline Constant & 2.6964 & .0790 & 34.1434 & .0000 & 2.5411 & 2.8518 \\
\hline $\begin{array}{c}\text { Public Self- } \\
\text { Consciousness(A) }\end{array}$ & .1543 & .0737 & 2.0934 & .0371 & .0093 & .2993 \\
\hline $\begin{array}{c}\text { Severity of } \\
\text { Incident(B) }\end{array}$ & -.4824 & .0677 & -7.1311 & .0000 & -.6155 & -.3494 \\
\hline $\mathrm{A} * \mathrm{~B}$ & -.0102 & .0460 & -.2210 & .8252 & -.1006 & .0803 \\
\hline
\end{tabular}

\section{5. 결론}

\section{1. 논의}

본 연구에서는 기업의 최고경영자가 부정적 행동을 저질렀을 때 이에 대해 소비자가 어떻게 반응하는가를 규명하고자 하였다. 그리고 최고경영자를 지지하려는 소비자가 있을 수 있음에 주목하고
최고경영자의 지지를 위한 주요한 정당화 기제의 결과요인과 영향요인을 규명하고자 하였다. 본 연구에서는 유명인의 부정적 행동에 대한 소비자 반응을 다룬 선행 연구에 근거하여 최고경영자의 스캔들에 대한 소비자 반응을 추론하고자 하였다. 본 연구의 이론적 근거가 되었던 연구들은 직접적으로 최고경영자의 스캔들을 다루고 있지는 않으나, 최고경영자가 강력한 브랜드로 기업의 평판에 영향을 미치고 있다는 점을 감안할 때 최고경영자를 유명인의 하위 범주로 볼 수 있다. 이에 본 연구에서는 최고경영자도 유명인만큼 소비자의 특정한 반응을 이끌어낼 수 있을 것이라 판단하고 일련의 가설을 제안하였다.

연구 결과, 도덕적 분리와 도덕적 합리화라는 정당화 기제는 기업의 윤리성 지각과 제품의 재구매의도에 긍정적 영향을 미쳤으며, 공적자기의식이 높은 소비자가 도덕적 합리화보다는 도덕적 분리를 더 많이 하는 것으로 나타났다. 다만, 본 연구에서는 사건의 심각성과 공적자기의식의 상호작용효과를 가설로 제안하였으며, 사건의 심각성이 낮은 경우에 공적자기의식이 높은 소비자가 도덕적 분리를 더 많이 할 것이라고 제안하였다. 그러나 이러한 상호작용효과는 기각되었는데, 왜 이러한 결과가 나타났는가에 대한 논의가 필요할 것이다. 본 연구에서는 최고경영자가 운전기사에게 폭언을 가한 사건을 연구의 대상으로 삼았다. 이 사건의 심각성 지각에 대한 설문참가자들의 응답은 7 점 척도 기준으로 평균 5.16 점인 것으로 나타났다. 즉, 사람들 대다수가 이 사건을 상당히 중요하고 심각한 사건으로 지각하였기 때문에 공적자기의식과 사건의 심각성 간의 상호작용효과가 지지되지 않은 것으로 판단된다. 이에 대해서는 본 연구의 한계점에서 재논의할 것이다.

\section{2. 학문적 시사점}

본 연구는 최근 최고경영자의 부정적 행동에 따른 소비자의 비판이 높아지고 있는 시점에서 최고경영자의 부정적 행동에 대한 소비자 반응을 정당화 기제와 관련된 선행연구에 근거하여 학술적으로 조명했다는 점에서 연구의 의의를 지닌다. 구체적으로, 본 연구는 최고경영자가 부정적 행동을 저질렀다고 하더라도 최고경영자를 정당화하려는 소비자가 존재할 수 있음에 주목하였다. 즉, 최고경영자의 부정적 행동 때문에 해당 기업에 등을 돌리는 소비자들도 있겠지만, 최고경영자의 부정적 행동에도 불구하고 그에게 우호적인 정당화 기제를 통해 해당 기업과의 관계를 지속하려는 소비자가 있을 수 있음을 제안하였다.

또한 본 연구는 정당화 기제의 영향요인으로 소비자의 개인적 특성인 공적자기의식을 제안하였으며, 공적자기의식이 높은 소비자가 낮은 소비자와 다른 정당화 기제를 보일 수 있음을 규명함으로써 윤리 관련 
연구, 그리고 유명인의 부정적 정보에 대한 소비자 반응을 다룬 연구의 영역을 확장하였다는데 나름의 의의가 있을 것이다.

\section{3. 실무적 시사점}

본 연구의 연구 결과는 기업의 위기관리전략과 관련된 실무적 시사점을 제공한다. 기업의 이미지 형성에 큰 영향을 미치며, 때로는 기업과 동일시되기까지 하는 최고경영자가 부정적 행동을 저질렀을 때 기업이 가장 우려하는 것은 소비자가 기업에 등을 돌림으로써 기업 성과가 하락하는 것일 수 있다. 일상을 살펴보면, 실제로 최고경영자가 물의를 일으키는 행동을 저질렀을 때 소비자들이 불매운동을 일으키며 해당 기업의 매출에 타격을 입히는 경우도 있다. 간장을 생산 판매하는 한 기업은 최고경영자가 운전기사에게 폭언과 폭행을 했다는 사실이 알려진 이후 소비자들의 불매운동으로 상당기간 매출이 급감하였다. 그러나 최고경영자가 부정적 행동을 저질렀을 때 모든 소비자들이 동일한 반응을 보이는 것은 아니다. 본 연구에서는 최고경영자를 옹호하려는 일부의 소비자들도 있을 수 있음을 규명하였으며, 이들은 최고경영자의 부정적 행동에 대해 우호적인 정당화를 함으로써 기업에 대해 긍정적 반응을 유지하려 함을 보였다.

이렇게 유명인의 부정적 행동에도 불구하고 이들에 대한 지지를 유지하려는 소비자 집단은 실제 사례에서도 찾아볼 수 있다. 예를 들면, 한 대기업 총수의 불륜과 혼외자에 대한 보도가 이루어졌을 때 이 대기업 총수의 행각을 로맨스로 해석하려는 소비자 집단이 존재했다. 그리고 해당 기업의 제품이나 서비스에 대한 소비자 불매운동은 앞선 경우와 달리 일어나지 않았다. 물론, 운전사에 대한 폭언은 타인에 대한 폭행이기 때문에 공적 사적에 해당되는 반면에, 불륜이나 혼외자의 문제는 개인 사생활에 해당되는 사적 사건이라고 볼 수 있다. 따라서 소비자들은 공적 사건보다는 사적 사건에 대해 덜 부정적으로 반응했을 가능성이 존재한다. 본 연구에서 제안하는 바는 모든 상황, 모든 사건에서 소비자가 최고경영자나 유명인의 부정적 행동에 대해 정당화 기제를 작동시킨다는 것을 제안하는 것이 아니다. 다만, 일부 소비자들이 해당 인물에 대한 지지를 철회하지 않기 위해 정당화 기제를 작동시킬 수도 있다는 점이다.

이러한 연구 결과가 기업에게 시사하는 바는 기업이 최고경영자로 인해 위기상황에 처하게 되더라도 이 위기에 모든 소비자들이 부정적으로 반응하지 않을 수 있다는 것이다. 기업 혹은 최고경영자가 위기상황에 대처하는 가장 효과적인 방법은 애초에 비도덕적인 행동을 저지르지 않는 것이다. 유명인으로서 최고경영자가 높은 윤리적 기준에 입각하여 사회에 공헌할 때 최고경영자의 윤리성과 기업의 윤리성은 높게 평가될 수 있으며, 이는 기업의 성과에 긍정적 영향을 미칠 수 있다. 그러나 최고경영자가 비도덕적 행동을 저질렀고, 이것이 소비자에게
알려졌을 때 기업이 주지해야 할 바는 모든 소비자들이 이에 대해 부정적으로 반응하지는 않는다는 것이다. 사건의 특성에 따라 우호적인 소비자 집단의 규모는 작거나 혹은 클 수 있겠으나 이러한 소비자가 일부 혹은 소수 존재한다면, 해당 기업은 이러한 우호적인 소비자의 의견을 결집하고 온라인상에서 확산시키는 방법을 통해 해당 위기가 기업 성과에 미치는 부정적 영향을 완화할 수 있을 것이다.

\section{4. 한계점 및 추후 연구 방향}

본 연구의 한계점과 이에 따른 추후 연구 방향은 다음과 같다.

첫째, 본 연구에서는 사건의 심각성을 실험으로 조작하기 보다는 설문으로 측정한 후 연속형 변수로 분석에 활용하였다. 그런데 사건의 심각성에 대한 응답자들의 응답이 상당히 높은 점수대로 분포하였기 때문에 공적자기의식과 사건의 심각성 간의 상호작용효과를 제안한 가설이 지지되지 않은 것으로 판단된다. 추후 연구에서는 심각성이 낮은 사건과 상대적으로 심각성이 높은 사건을 선별하여 실험으로 조작하는 방법을 통해 본 연구의 가설을 재검증해볼 필요가 있다.

둘째, 본 연구에서는 최고경영자에게 우호적인 정당화 기제가 높게 나타날 수 있는 상황에 한정하여 연구를 진행하였다. 우선, 최근 제품을 구입한 적이 있는 기업의 최고경영자에 대한 신문기사를 응답자들에게 개별적으로 제시한 후 이러한 신문기사에 대한 설문에 응답하도록 하였다. 즉, 응답자들은 이미 자신과 관계를 형성한 적이 있는 기업이기 때문에 한 번도 제품을 구입한 적이 없는 기업과 비교했을 때 횔씬 더 기업에 대해 높은 애착(attachment)이나 몰입(commitment)을 형성했을 가능성이 높다. 따라서 자신과 호의적인 관계를 형성하고 있는 기업의 최고경영자가 부정적인 행동을 저질렀다고 하더라도 이에 대해 정당화할 가능성이 높을 수 있다는 것이다. 또한 본 연구에서는 Bhattachajee et al.2013)의 연구 방법을 참고하여 최고경영자에 대한 긍정적 정보(훌륭한 경영능력)와 부정적 정보(운전기사에게 폭언)를 동시에 제공한 후 이에 대한 소비자 반응을 규명하였다. 이렇게 소비자들은 불일치하는 정보를 접했을 때 긍정적 정보나 부정적 정보의 가중치를 조정함으로써 불일치를 해결하고 인지적 불편함을 해소하려 한다. 본 연구 맥락에 적용해보면, 소비자가 이미 해당 기업과 관계를 형성한 상황에서 최고경영자에 대한 부정적인 정보와 긍정적인 정보를 접하게 되었을 때 소비자들이 인지적 불편함을 해소하고 인지적 균형 상태에 이르기 위한 방법 중 하나는 최고경영자에게 우호적인 정당화 기제를 함으로써 최고경영자에 대한 부정적 평가를 완화하는 것일 수 있다. 즉, 본 연구에서는 정당화 기제가 나타나기 용이한 상황에 한정하였으나, 소비자가 제품을 구입한 적이 없는 기업이나 혹은 최고경영자의 경영능력이 없는 상황에서는 이러한 정당화 기제가 나타나지 않을 수 있다. 추후 연구에서는 기업과 소비자의 관계의 질적 
측면이나 최고경영자에 대한 정보의 극성(valence)에 따라 소비자의 반응이 어떻게 달라지는가를 연구해볼 수 있을 것이다.

셋째, 본 연구에서는 최고경영자가 운전기사에게 폭언을 가한 한 가지 상황에 한정지어 연구를 진행하였다. 이러한 상황은 실제 일어난 사건에 착안하여 설정된 것이지만, 기업이나 최고경영자가 저지르는 부정적 행동은 다양한 형태로 분류될 수 있다. 예를 들면, 소비자가 지각한 심각성을 기준으로 보다 심각한 사건과 덜 심각한 사건이 있을 수 있다. 또한 브랜드 측면에서 보면, 기업 혹은 제품 브랜드와 본질적으로 연관된 핵심 사건과 비핵심사건(예. 사회적 책임을 다하지 못하는 것과 관련된 브랜드 위기 상황)으로 분류될 수도 있을 것이다. 즉 최고경영자의 부정적 행동이 다양한 유형으로 분류될 수 있으며, 이러한 유형의 특성에 따라 소비자의 반응도 달라질 수 있을 것임을 시사한다. 추후 연구에서는 최고경영자의 부정적 행동을 여러 측면에서 유형화하여 이에 따른 소비자의 차별적 반응을 검증해볼 필요가 있다.

\section{References}

Bhattacharjee, A., Berman, J. Z., \& Reed, A. (2013). Tip of The Hat, Wag of The Finger: How Moral Decoupling Enables Consumers to Admire and Admonish. Journal of Consumer Research, 39(6), 1167-1184.

Brammer, S., \& Millington, A. (2005). Corporate Reputation and Philanthropy: An Empirical Analysis. Journal of Business Ethics, 61(1), 29-44.

Cho, H. Y., \& Ju, Y. H. (2015). The Influence of Super-Centers' Social Responsibility Activities and Authenticity On Consumer Attitude and Purchase Intention. Journal of Distribution Science, 13(2), 35-44.

Choi, J., Lee, S., \& Jang, E. (2013). The Impact of Public SelfConsciousness, Narcissism, and Brand Concept on Brand Fan Page Share Intention. Korean Journal of Marketing Research, 28(2), 65-86.

Fenigstein, A., Scheier, M. F., \& Buss, A. H. (1975). Public and Private Self-Consciousness: Assessment and Theory. Journal of Consulting and Clinical Psychology, 43(4), 522-527.

Godfrey, P. C. (2005). The Relationship Between Corporate Philanthropy and Shareholder Wealth: A Risk Management Perspective. Academy of Management Review, 30(4), 777-798.

Haberstroh, K., Orth, U. R., Hoffmann, S., \& Brunk, B. (2017). Consumer Response to Unethical Corporate Behavior: A ReExamination and Extension of the Moral Decoupling Model. Journal of Business Ethics, 140(1), 161-173.

Hahn, Y. (2015). IKEA and Corporate Social Responsibility: A Case Study. Journal of Distribution Science, 13(10), 45-50.

Haidt, J. (2001). The Emotional Dog and Its Rational Tail: A Social Intuitionist Approach to Moral Judgment. Psychological Review, 108(4), 814-834.
Hayes, A. F. (2009). Beyond Baron and Kenny: Statistical Mediation Analysis In The New Millennium. Communication Monographs, 76(4), 408-420.

Jun, S. Y., Ju, T. W., \& Jun, H. J. (2009). Effects of Information Provider on Consumer's Attitude toward a Brand Crisis: Who Should Announce the Truth of a Brand Crisis?. Korean Journal of Marketing Research, 26(2), 25-44.

Kang, B. (2018). The Effect of Corporate Ethicality Perception on Word-of-Mouth Intention: The Mediating Effects of Corporate Identification, Trust, and Loyalty. Korean Journal of Marketing Research, 33(3), 1-23.

Kunda, Z. (1990). The Case For Motivated Reasoning. Psychological Bulletin, 108(3), 480-498.

Laufer, D., Gillespie, K., Mcbride, B., \& Gonzalez, S. (2005). The Role of Severity in Consumer Attributions of Blame: Defensive Attributions in Product-Harm Crises in Mexico. Journal of International Consumer Marketing, 17(2-3), 33-50.

Lee, D. G., \& Lee, M. J. (2014). The Effect of Corporate Social Responsibility on Corporate Image and Corporate Performance. Journal of Distribution Science, 12(9), 101-112.

Lee, J. S., Kwak, D. H., \& Moore, D. (2015). Athletes' Transgressions and Sponsor Evaluations: A Focus on Consumers' Moral Reasoning Strategies. Journal of Sport Management, 29(6), 672-687.

Miller, F. G., Davis, L. L., \& Rowold, K. L. (1982). Public SelfConsciousness, Social Anxiety, and Attitudes Toward The Use of Clothing. Home Economics Research Journal, 10(4), 363368.

Park, J., Choi, J., \& Yeu, M. (2016). Relationship Between Corporate Philanthropy and Consumer Loyalty-The Mediating Role of Gratitude, Trust and Commitment: South Korean Consumer Perspectives. Academy of Marketing Studies Journal, 20(1), 1-17.

Raykov, T. (1997). Estimation of Composite Reliability for Congeneric Measures. Applied Psychological Measurement, 21(2), 173-184.

Shim, M., Lee, M. J., \& Park, S. H. (2008). Photograph Use On Social Network Sites Among South Korean College Students: The Role of Public and Private Self-Consciousness. Cyberpsychology \& Behavior, 11(4), 489-493.

Turner, R. G., Gilliland, L., \& Klein, H. M. (1981). SelfConsciousness, Evaluation of Physical Characteristics, and Physical Attractiveness. Journal of Research in Personality, 15(2), 182-190.

Vlachos, P. A., Tsamakos, A., Vrechopoulos, A. P., \& Avramidis, P. K. (2009). Corporate Social Responsibility: Attributions, Loyalty, and The Mediating Role of Trust. Journal of The Academy of Marketing Science, 37(2), 170-180.

Williams, R. J., \& Barrett, J. D. (2000). Corporate Philanthropy, Criminal Activity, and Firm Reputation: Is There A Link? Journal of Business Ethics, 26(4), 341-350.

Zhang, Y. (1996). Responses to Humorous Advertising: The Moderating Effect of Need for Cognition. Journal of Advertising, 25(1), 15-32. 